\title{
Yhteistoiminnallisen oppimisen teoreettista taustaa
}

\author{
Suomeen on viimeisen kolmen \\ vuoden aikana levinnyt innostus \\ soveltaa yhteistoiminnallisen \\ oppimisen periaatteita opetukseen \\ ja koulun kehittämiseen. \\ Yhdysvaltalaiset professorit Roger \\ ja David Johnson ovat tämän \\ menetelmän tärkeimpiä kehittäjiä, \\ ja heidän opetukseensa suomalaiset \\ sovellutukset paljolti perustuvat. \\ Tässä artikkelissa \\ yhteistoiminnallisella oppimisella \\ tarkoitetaan lähinnä juuri \\ Johnsonien kehittämää \\ "oppisuuntaa".
}

Yhteistoiminnallisessa oppimisessa korostetaan kilpailun ja yksilöllisen työskentelyn sijasta oppimista ja opiskelua toisten oppilaiden kanssa. Erilaisten opetuksellisten ratkaisuiden avulla vaikutetaan siihen, että ryhmissä syntyisi positiivinen keskinäinen riippuvuus: jos sinä voitat, minäkin voitan. (Johnson \& al. 1984, 8.)

Useille opettajille yhteistoiminnallisen oppimisen sovellutukset eivät ole uusia. Varsinkin jos opettaja on itse ollut kiinnostunut vähentämään oppilaiden välistä kilpailua ja suuntaamaan oppilaiden energiaa yhteiseen onnistumiseen, hän on saattanut päätyä hyvinkin samanlaisiin työskentelytapoihin kuin Johnsonit. Kyseessähän ovat pitkälti perinteisen luokkatyöskentelyn ongelmat, sellaiset ikuisuuskysymykset kuin oppilaiden heterogeenisyys, työrauhan turvaaminen tai oppimismotivaatio, joihin opettajat eri puolilla maailmaa etsivät jatkuvasti uusia ratkaisuja.

Pinnallisesti sovellettuna yhteistoiminnallinen oppiminen saattaa näyttäytyä opettajille ja oppilaillekin vain joukkona erityisiä opetusmenetelmiä. Oppilaista voi vaikuttaa siltä, että kyseessä on jännittävä uusi peli, johon he pian kuitenkin kyllästyvät. Aikuisopiskelija voi puolestaan kieltäytyä olemasta opettajan pelinappula, jota siirrellään eri ryhmiin useaan kertaan oppitunnin aikana.

Yhteistoiminnallinen oppiminen ei kuitenkaan ole pelkkä peli tai opetustekniikka, vaan se on synteesi David ja Roger Johnsonin pitkästä opetus- ja tutkimustyöstä.Tässä artikkelissa paneudutaan opetusmenetelmän taustaan eli selvitetään sitä, minkälaiseen teoreettiseen ja empiiriseen tietoon menetelmä perustuu. Erityisen kiinnostuksen kohteena ovat menetelmän sosiaalipsykologiset kytkennät. Tällä tarkoitetaan sitä, millaisia ryhmiä ja yksilöitä koskevia teorioita tähän lähestymistapaan liittyy ja mihin ne asettuvat sosiaalipsykologian kentässä. Koska suomalaiset opettajat ovat tutustuneet menetelmään lähinnä käytännön tasolla, menetelmän teoreettisten ja historiallisten taustojen esittely suomenkielellä lienee tarpeellinen ja tervetullut.

\section{Yhteistoiminnallisen oppiminen pähkinänkuoressa}

Yhteistoiminnallisuudella tarkoitetaan työskentelyä yhteisten tavoitteiden saavuttamiseksi (Johnson \& al. 1984, 2). Oppimisesta tulee yhteistoiminnallista, kun opettaja rakentaa opetuksensa siten, että oppilaat ovat riippuvaisia toisistaan saavuttaakseen oppimistavoitteen. Kilpailutilanteessa oppilaat ovat negatiivisesti riippuvaisia toisistaan (kaikki eivät voi kirjoittaa ylioppilaskokeissa laudaturia tai kaikki eivät yleensä voi saada kymppiä kokeesta). Jos oppilaat sen sijaan huomaavat, että sinun voittosi on 
myös minun voittoni ja että yhdessä voimme päästä pidemmälle kuin kukaan yksin, he alkavat suosia yhteistoimintaa kilpailun sijasta. Tällöin on kyse positiivisesta riippuvuudesta toisiin ihmisiin. (Johnson \& al. 1984, 2-8.)

Tämä positiivisen rippuvuuden periaate on keskeinen yhteistoiminnallisessa oppimisessa. Vaikka joissakin yhteistoiminnallisen oppimisen menetelmissä tämä positiivinen riippuvuus luodaan keinotekoisesti, päämääränä on kuitenkin antaa oppilaille mahdollisuus aidosti kokea se, että yhdessä työskentelmällä kaikki oppivat paremmin.

Yhteistoiminta vaatii sosiaalisia taitoja, jotka syntyvät vain harjoittelemalla. Siksi sosiaalisten ryhmätaitojen sekä vuorovaikutteisen viestimisen harjoittelu kuuluvat tärkeänä osana yhteistoiminnalliseen oppimiseen. Työskentely tapahtuu yleensä 2-4 hengen ryhmissä ja ryhmän jäsenten tulee olla mahdollista työskennellä kasvokkain. Näillä järjestelyillä mahdollistetaan avoin ja monipuolinen vuorovaikutus oppilaiden välillä. (Johnson \& al. 1984, 8; Sahlberg \& Leppilampi 1993.)

Vaikka oppiminen tapahtuu yhdessä toisia auttaen, jokaisella on vastuu omasta oppimisestaan. Jos esimerkiksi ryhmän kukin jäsen vastaa yhdestä projektin osa-alueesta, lopputulos tulisi olla, että kaikki hallitsevat kaikki osa-alueet. Esimerkiksi yksilölliset kokeet ryhmäopiskelun jälkeen selvittävät, onko tämä tavoite saavutettu. (Johnson \& al. 1984, 23; Sahlberg \& Leppilampi 1993.)

Lisäksi tärkeätä yhteistoiminnallisessa oppimisprosessissa on edistymisen arviointi. Arvioinnin kohteena on toisaalta opiskeltavan aiheen hallinta ja toisaalta ryhmätyötaitojen kehittyminen. Tätä arviointia tehdään ryhmässä yhdessä muiden opiskelijoiden kanssa ja myös opettaja antaa palautetta oppilaille heidän edistymisestään vuorovaikutustaidoissa. (Johnson \& al. 1984, 23.) Aidossa yhteistoiminnallisessa luokassa myös oppilailla lienee mahdollisuus antaa opettajalle palautetta hänen yhteistyötaidoistaan.

Opettajan rooli on lähempänä oppimisen ohjaajaa kuin perinteistä tiedon jakaajaa. Keskeis- tä opettajan työssä on lisäksi opetuksen huolellinen suunnittelu. Lisäksi hän vastaa Johnsonien mukaan $(1984,26)$ oppilaiden jakamisesta ryhmiin.

Yhteistoiminnallisen oppimisen periaatteiden toteuttamiseksi on kehitetty useita kymmeniä erilaisia työmenetelmiä (Slavin 1985). Näitä työmenetelmiä voi soveltaa aluksi vaikkapa vain tavallisen luokkatyöskentelyn ryhmätyöosiin. Yhteistoiminnallinen oppiminen on kuitenkin lähestymistapa, jonka käyttö voi parhaillaan laajentua luokkahuoneesta opettajien kollegiaalisiin tukiryhmiin tai koulun sisäiseen kehittämiseen saakka. (Ks. esim. Kohonen \& Leppilampi 1992.) Johnson \& Johnson (1992) esittävät jopa mallin, jossa yhteitoiminnallisuus tulisi ulottaa kunnan kouluviranomaisten työskentelyperiaatteisiin saakka, jotta yhteistoiminnallisen koulun johtamiskulttuuri olisi yhtenäinen uuden työskentelykulttuurin kanssa.

\section{Ryhmädynamiikan tutkimuksen varhaisvaiheet ja Kurt Lewinin panos}

Yhteistoiminnallisen oppimisen menetelmä perustuu tietoon ryhmien toiminnasta ja ihmisestä ryhmän jäsenenä. Sitä sosiaalipsykologian osa-aluetta, joka tutkii ryhmien toimintaa kutsutaan ryhmädynamiikaksi. Se, miten ja millä ehdoilla ihmiset toimivat ryhmissä yhteistoiminnallisesti eivätkä kilpaillen tai pelkästään omiin yksilöllisiin tavoitteisiin pyrkien, on ollut yksi keskeisimmistä kysymyksistä ryhmädynamiikan alalla lähes koko kuluvan vuosisadan ajan. (Johnson \& Johnson 1987, 11-12.)

Ryhmien toiminnan lainalaisuudet lienevät niitä kysymyksiä, joiden pohdintaa ovat harjoittaneet jo varhaiset filosofit. Johnsonien (1987, 12) mukaan $1900-l u v u n$ ryhmädynamiikan tieteellistä syntyä edelsi kolmensadan vuoden aika, jolloin ryhmiin liittyvät perusoletukset syntyivät ja niistä keskusteltiin muiden tieteenalojen yhteydessä.

1930-luvun lopulta alkoi nopea ryhmädynamiikan tutkimuksen kehitys amerikkalaisten sosiologien keskuudessa. Johnsonit (1987, 12) 
mainitsevat Sherifin ryhmänormien syntymistä käsitelleet kokeet, Newcombin college-opiskelijoiden poliittisia asenteita ja sosiaalisia normeja käsittelevän tutkimuksen sekä Whyten Bostonin Norton Streetin jengitutkimuksen. Sherifin 1930-luvulla tehdyssä klassisessa kokeessa tutkittiin sitä, miten ryhmän muiden jäsenten mielipiteet vaikuttivat epäselvän ärsykkeen (valopisteen liikkeen) havaitsemiseen pimeässä huoneessa. Newcombin kenttätutkimus (1943) valotti vertaisryhmän liberaalien asenteiden vaikutusta opiskelijoiden asenteisiin, vaikka suurin osa tutkittavista oli konservatiivisista kodeista. Myös jengitutkimus (1937-41) osoitti ryhmien keskeisen roolin yksilöiden elämässä, mutta myös yhteiskunnan toiminnassa.

Varsinainen ryhmädynamiikan tutkimuksen uranuurtaja oli kuitekin Mogilnon kylästä Preussista (nykyisin Puolassa) kotoisin oleva Kurt Lewin. Vuonna 1890 syntynyt Lewin opiskeli aluksi Berliinin yliopistossa ja kuului hahmopsykologien koulukuntaan. Pääasiallisen työnsä ryhmien tutkimuksen alalla hän teki kuitenkin Yhdysvalloissa, jonne hän siirtyi 1930-luvulla juutalaisten vainoa pakoon. (Schellenberg, 1988, 64-66.)

Lewinin työssä sosiaalisten ilmiöiden tutkijana voi nähdä kolme pääperiaatetta (Johnson \& Johnson, 1987, 14). Ensinnäkin soveltavan tutkimuksen tekeminen. Hän uskoi, että sosiaalipsykologian tutkimuksien avulla voidaan ratkaista yhteiskunnan polttavia ongelmia. Toiseksi hän oli kekseliäs kokeellisten asetelmien kehittelijä, josta hyvänä esimerkkinä on hänen inspiroimansa, mutta Lippitin ja Whiten 1938-39 suorittama johtajuusilmastotutkimus. Tutkimuksessa vertailtiin autoritaarisen ja demokraattisen ja myöhemmin laissez-faire-tyyppisen johtamistavan vaikutusta lasten leikkiryhmiin. (Schellenberg, 1988, 69.)

Kolmanneksi ja ennen muuta Kurt Lewin oli teoreetikko. Hänen lempisanontojaan oli: "Mikään ei ole niin käytännöllistä kuin hyvä teoria". Hänen ihmisen toimintaa käsittelevää teoriaa kutsutaan kenttäteoriaksi. Lewinin mukaan meidän täytyy tuntea ihmisen psykologisessa kentässä vaikuttavien voimien kokonaisuus, jotta voisimme ymmärtää hänen käyttäytymistään. (Schellenberg, 1988, 56-62.) 1930-luvun puolesta välistä saakka Lewin osallistui Yhdysvalloissa erilaisiin sosiaalista muutosta käsitteleviin toimintatutkimuksiin. Usein mainittu on perheenäitien ravintotottumusten muutosprojekti, joka toteutettiin toisen maaimansodan aikana. Oman juutalaisen taustansa takia Lewin oli erityisen kiinnostunut osallistumaan työhön, jossa paneuduttiin ennakkoluulojen ja diskriminaation vähentämiseen.

Useiden sosiaalista muutosta käsittelevien tutkimustensa pohjalta Lewin havaitsi, että yksilöiden on helpompaa muuttua, jos he kuuluvat ryhmään, ja tekevät ryhmäpäätöksen muuttumisesta. Jos ryhmän normit ensin muuttuvat, yksilöiden on muututtava sopeutuakseen ryhmään. Jos taas yritetään vaikuttaa pelkästään yksilöön, hänen on muututtava eri suuntaan kuin mitkä ryhmän normit ovat.

Vähitellen Lewin kokosi ympärilleen joukon oppilaita ja työtovereita, ja hänen johdollaan perustettiin ryhmädynamiikan tutkimuskeskus Massachusetts Institute of Technologyn yhteyteen vuonna 1945. (Schellenberg, 1988.)

Lewinin työtapa oli hyvinkin demokraattinen eli keskinäistä riippuvuutta ja tasa-arvoisuutta korostava. Hän oli parhaimmillaan epävirallisten seminaariryhmien vetäjänä ennemminkin kuin luennoitsijana. Marrow $(1969,127)$ kertoo Lewinin entisen kollegan Robert Searsin joskus ihmetellen sitä, kuinka autoritaarisesti Lewin vaatikaan demokratiaa.

\section{Morton Deutsch - yhteistoiminnan ja kilpailun tutkija}

Morton Deutsch oli yksi Lewinin oppilaista. Vuonna 1920 syntynyt Deutsch aloitti jatkoopintonsa M.I.T:N ryhmädynamiikan tutkimuslaitoksessa 1945. Lewinin 100-vuotissyntymäpäivän kunniaksi pidetyssä seminaarissa Helsingissä Deutsch (1990) kertoo Lewinin innostavasta ja tasa-arvoisesta suhtautumisesta häneen ja tunnustaa Lewinin työtapojen ja käsityksen tieteestä vaikuttaneen suuresti hänen tekemäänsä tieteelliseen työhön.

Morton Deutschin väitöskirja yhteistoiminnan ja kilpailun teoriasta (A theory of coopera- 
TAULUKKO 1. RYHMÄN TAVOITERAKENTEET JA YKSILÖIDEN VÄLISET PROSESSIT (Johnson \& Johnson 1987, 152-153

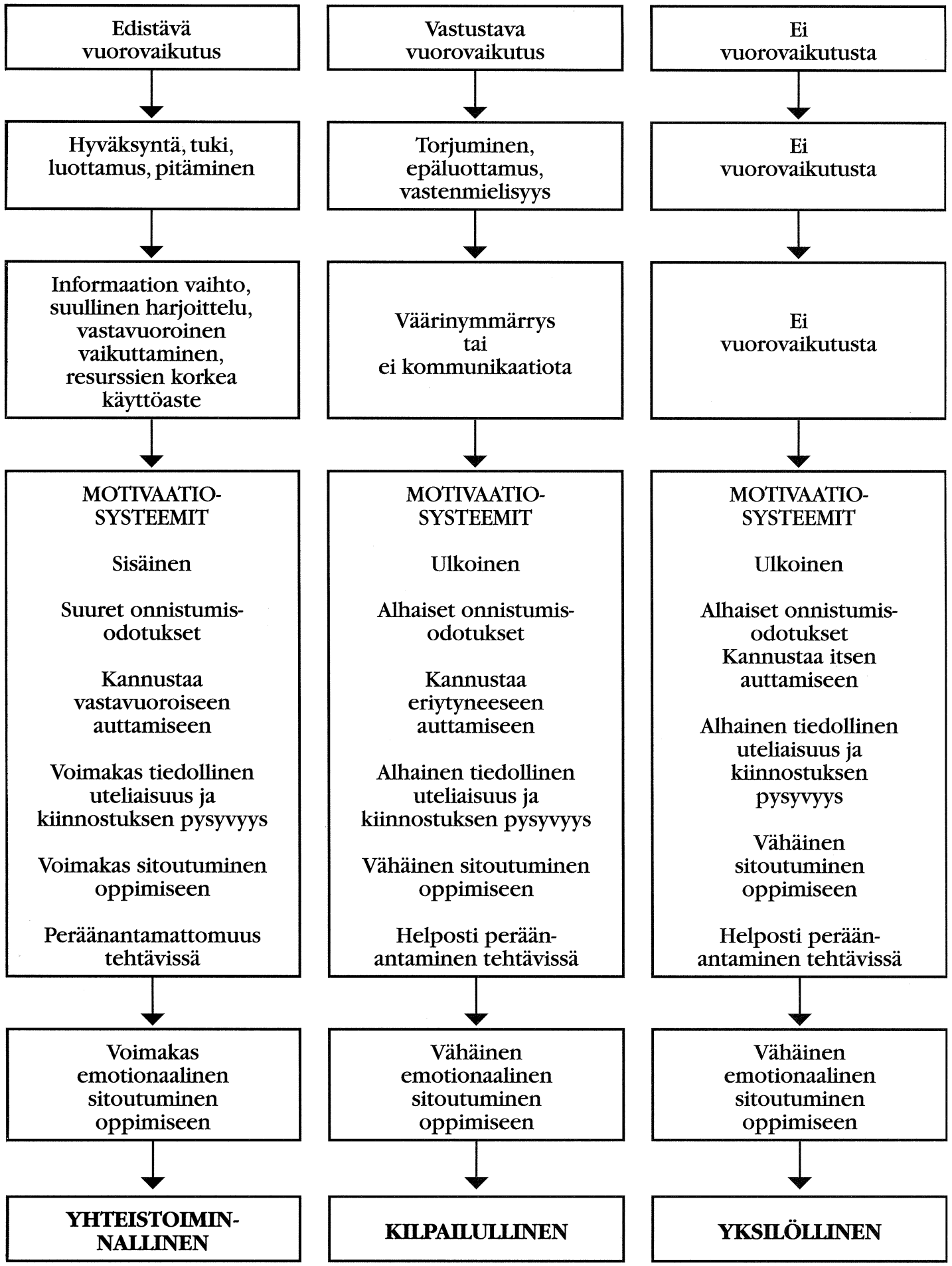


tion and competition) ilmestyi vuonna 1949. Hänen kiinnostuksensa kohdistui aluksi sodan ja rauhan kysymyksiin ja vasta perustetun YK:n turvallisuuspalvelun toimintamahdollisuuksiin. Ryhmädynamiikan laitoksen henki suuntasi hänen mukaansa kuitenkin tutkimusta kohti teoreettisempaa otetta. (Deutsch, 1990, 17.)

Deutschin teoria perustui Lewinin kenttäteoriaan. Kenttäteorian mukaan ihmisen käyttäytyminen on tavoitteisiin suuntautunutta. Niin kauan kuin ihminen ei ole saavuttanut tavoitettaan, tensiojärjestelmät pitävät yllä käyttäytymistä, mutta kun tavoite on saavutettu tensio (ekspansiovoima) vähenee. Yhteistoiminnan ja kilpailun teoriassa oli kiinnostuksen kohteena se, kuinka eri ihmisten tensiosysteemit ja siten myös tavoitteet ovat suhteessa toisiinsa. (Johnson \& Johnson, 1989, 7-8.)

Deutschin teorian mukaan ihmisten välillä on kahdenlaista sosiaalista riippuvuutta (interdependence): yhteistoiminnallista ja kilpailullista. Lisäksi yksilöllisestä työskentelystä tai yksilöllisesti omiin päämääriin pyrkimisestä puuttuu riippuvuus toisiin ihmisiin.

Johnson \& Johnsonin (1989) mukaan Deutschin teoria on erittäin merkittävä sosiaalipsykologian teoria, mistä on osoituksena se, että 40 vuoden ajan sen pohjalta on jatkuvasti tehty sekä teoreettisia että empiirisiä tutkimuksia. Lisäksi Deutsch on itse jatkanut tutkimusta ja pohtinut mm. luottamuksen merkitystä yhteistyön synnyssä, konfliktienratkaisua sekä jakamisen oikeutta (distributive justice).

Sivun 17 taulukon ovat Johnson \& Johnson (1987, 153-154) koonneet Deutschin sosiaalisen riippuvuuden -teoriaan perustuvien tutkimuksien tuloksista. Näissä tutkimuksissa on vertailtu yhteistoiminnallisten, kilpailullisten ja yksilöllisten tavoitteiden vaikutusta sellaisiin ryhmän vuorovaikutuksen muotoihin, jotka ovat tärkeitä ryhmän tuotteliaisuuden, moraalin tai tehokkuuden kannalta. Oheinen taulukko on lainattu em. teoksesta (käännös kirjoittajan)

Ryhmän tavoitteisiin liittyvä tutkimus on osoittanut, että jokainen tavoiterakenne eli se, ovatko yksilöiden tavoitteet positiivisesti vai negatiivisesti riippuvaisia toisistaan, aiheuttaa ryh- män jäsenten välillä erilaisen vuorovaikutuksen muodon. Ryhmän vuorovaikutuksen muoto taas vaikuttaa ryhmän toimintaan ja tulokseen. Esimerkiksi positiivinen riippuvuus ryhmän jäsenten tavoitteiden välillä edistää vastavuoroista auttamista, joka taas vaikuttaa pitämisen ja luottamuksellisen ilmapiirin syntymiseen ryhmässä. Lisäksi ryhmän jäsenet käyttävät toisiaan tietolähteinä ja toisaalta vaikuttavat toistensa asenteisiin ja johtopäätöksiin. Motivaatio oppia tulee sisäiseksi ja ryhmän jäsenet ovat valmiita sitoutumaan emotionaalisesti oppimisprosessiin.

Sen sijaan kilpailullisessa ryhmässä ryhmä saattaa vaikuttaa estävästi yksilön oppimiseen. Yksilöllisiin tavoitteisiin pyrkivä henkilö rajaa toiset ihmiset kokonaan pois oppimisprosessin auttajana, jolloin yksilö on vain omien tietojensa ja kykyjensä varassa.

David Johnson, toinen yhteistoiminnallisen oppimisen kehittäjistä on ollut Morton Deutschin oppilas ja työtoveri 1960-luvulta asti. David Johnson aloitti sosiaalipsykologian opintonsa Morton Deutschin oppilaana vuonna 1963 Columbian yliopistossa New Yorkissa. Roger Johnson, toinen yhteistoiminnallisen oppimisen kehittäjistä oli opiskellut opettajaksi ja 1960-luvun lopulta lähtien nämä kaksi veljestä ovat työskennelleet yhteistä päämäärää kohti: kehittää yhteistoiminnallisen oppimisen teoriaa ja sovellutuksia sekä toteuttaa aiheeseen liittyvää tutkimusta. (Johnson \& Johnson, 1989.)

\section{Pohdinta}

Jos David ja Roger Johnsonia voidaan pitää yhteistoiminnallisen oppimisen isinä, olisi Morton Deutsch tämän menetelmän isoisä ja Kurt Lewin yhteistoiminnallisen oppimisen isoisoisä. Kurt Lewinin sosiaalisesti mielekkään tutkimuksen painottaminen sekä käsitys teorian ja käytännön kiinteästä yhteydestä näkyy myös yhteistoiminnallisen oppimisen menetelmän kehittämisessä tiiviisti tutkimuksen ja teorianmuodostuksen rinnalla.

Sekä Kurt Lewin että Morton Deutsch halusivat omalla työllään vaikuttaa ihmisten välisten konfliktien rauhanomaiseen ratkaisemiseen ja esimerkiksi rotujen välisten ennakkoluulojen 
lieventämiseen. Myös yhteistoiminnallinen oppiminen antaa välineitä lieventää esimerkiksi koululuokkaan kuuluvien eri rotuisten oppilaiden välisiä ennakkoluuloja (Slavin, 1985, 11-14).

Vaikka tässä työssä on rajauduttu lähinnä David ja Roger Johnsonin kehittämään yhteistoiminnallisen oppimisen menetelmään, sekä Yhdysvalloissa että muualla maailmassa, esimerkiksi Tel Avivissa Israelissa, on useita tutkijoita, jotka tutkivat ja kehittävät menetelmää. Tel-Avivin yliopistossa yhteistoiminnallista oppimista kehitetään Shlomo Sharanin johdolla. Toinen merkittävä tutkija on Robert E. Slavin The Johns Hopkins yliopistossa Baltimoressa, Marylandissa.

Samanlaisia, yhteistoiminnallisuuteen perustuvia ideoita on syntynyt myös liike-elämässä. Yhdysvalloista lähtöisin olevat ja Japanin kautta Suomeenkin tulleet laatupiirit ovat kuuluneet 1980-luvulla työelämän kehittämisen uusiin tuuliin (Sarala, 1993). 1990-luvulla verkosto-ajattelu on nostanut päätään (Aikuiskoulutuksen maailma, 1993, 10-16) ja ainakin tasa-arvoinen työskentely yhdessä, ja ihmisten riippuvaisuus ainakin osittain toisistaan ovat yhteistä verkostotyöskentelymallille ja yhteistoiminnalliselle oppimiselle.

Suomessa menetelmästä ovat innostuneet niin lasten ja nuorten opettajat kuin aikuiskasvattajatkin. Aikuisten opiskelussa korostuu uuden tiedon kytkentä aikaisempiin tieto- ja toimintarakenteisiin. Menetelmä soveltuukin juuri erityisen hyvin aikuisten opiskeluun, koska yhteistoiminnallinen oppiminen on parhaimmillaan tiedon yhteistä rakentamista opiskelijoiden ammatillisten ja elämänkokemusten pohjalta tasa-arvoisessa vuorovaikutuksessa aikuisopettajan ja muiden opiskelijoiden kanssa. Menetelmän soveltamisen kynnystä aikuisryhmiin madaltanee aikuisuuteen liittyvä kyky ottaa vastuuta sekä omasta että toisten toiminnasta. Suomessa on saatu rohkaisevia kokemuksia menetelmän käyttökelpoisuudesta sekä ammatilliselta puolelta että vapaan sivistystyön ja yliopiston alalta.

Kurt Lewinin kenttäteorian mukaisesti Morton Deutsch on määritellyt yhteistoiminnan pyr- kimiseksi yhteisiin tavoitteisiin. Argylen (1991, 20) mukaan Deutschin määritelmä selittää vain osittain sitä, miksi ihmiset toimivat yhdessä. Yhteisen tavoitteen saavuttamisen lisäksi ihmiset toimivat yhdessä, koska he näin pitävät yllä niitä sosiaalisia suhteita, joita elämässä tarvitaan. Tämä evolutionaaliseen ajatteluun perustuva väite sisältää sen, että meissä on sisäänrakennettuja motivationaalisia systeemejä, jotka varmistavat sen, että yhteistoiminta tuottaa iloa. Tästä esimerkkinä Argyle mainitsee seksuaalisen kanssakäymisen tai lapsen ja äidin välisen suhteen.

Lisäksi Argyle väittää, että synkronisoitu vuorovaikutus, jota tapahtuu esimerkiksi ihmisten tanssiessa tai pelatessa jotain peliä tai musiikin tekemisessä on myös sinällään palkitsevaa ja siitä seuraa, että ihmiset alkavat pitää toisistaan. Yhteistoiminta siis sinällään on tässäkin suhteessa tavoite, eikä tavoite ole jossain tuotoksessa tai tuloksessa, kuten Deutsch asiaa painottaa. (Argyle, 1991, 20-22.)

Argylen väitteet tuovat lisävalaistusta yhteistoiminnalliseen oppimiseen, ja vaikka hän kritisoi Deutschin määritelmää liian suppeaksi, en katso että tämä näkökulma kuitenkaan kumoaa yhteistoiminnallisen oppimisen tärkeyttä. Pikemminkin Argylen väitteet korostavat, että yhteistoiminta sinänsä on palkitsevaa, vaikka ryhmällä ei olisikaan mitään yhteistä tavoitetta. Tämä "vaara" onkin usein havaittu ryhmätyöskentelyssä, jossa pyritään tavoitteeseen. Työryhmä tai opintopiiri alkaa viihtyä niin hyvin yhdessä, että työhön liittyvä tavoite unohtuu.

Yhteistoiminnallisuuden periaatteisiin tutustuminen on mielestäni suositeltavaa kaikille opettajille, jotka ovat kiinnostuneita oman ammattitaidon laajentamisesta. Sen pohjalta voi ryhtyä muuttamaan opetustapaansa enemmän yhteistoimintaa suosivaksi. Menetelmä antaa myös välineitä nähdä, miten sisäänrakentunutta kilpailu on omassa opetuksessa ja myös koulun ja yhteiskunnan rakenteissa.

Yhteistoiminnallisen oppimisen periaatteet ovat lähellä demokraattisuuden ihannetta. Myös opettajan rooli etääntyy voimakkaasta autoritaarisuudesta lähemmäksi yhteistyöntekijää, kanssaoppijaa. Billig \& al. (1988) väittävät kir- 
jassaan "Ideological Dilemmas", että opettaja on opetustilanteessa kuitenkin aina auktoriteetti, joskin vallitsevat demokraattiset arvot pakottavat pukemaan vallankäytön demokraattiseen valeasuun. Vaikka autoritaarisuuden ja demokraattisuuden ideologiat ovat toisilleen vastakkaisia, ilman toista ei voi olla toista. Tämä vastakkaisuus ja ideologien dialektinen suhde juuri mahdollistavat niiden olemassaolon.

Tutustuttuaan yhteistoiminnallisen oppimisen menetelmään opettaja saattaa innostua siitä, että hän on vihdoinkin löytänyt opetusmenetelmän, joka vastaa hänen omaa demokraattista arvomaailmaansa. Jos omaa uskoa menetelmään vielä vahvistavat oppilaiden paremmat oppimistulokset, saattaa opettaja ryhtyä "levittämään sanaa" ja toimimaan ponnekkaasti yhteistoiminnallisen oppimisen puolestapuhujana. Silloin hän on kuitenkin putoamassa autoritaarisuus - demokraattisuus - dilemman sudenkuoppaan. Hän toimii kuin Kurt Lewin vaatiessaan autoritaarisesti demokraattisuutta.

Mutta millaista olisi yhteistoiminnallisen oppimisen soveltaminen yhteistoiminnallisesti? Jos opettaja on aidosti yhteistoiminnallinen oppilaittensa kanssa, eikö lopputulos voi olla jotakin muuta kuin yhteistoiminnallinen oppiminen? Ainakin tämä aitouden vaatimus asettaa opettajan toiminnalle uusia kriteereitä ja opettajan tulisikin mielestäni alkaa oman toiminnan kriittinen tarkastelu, mikä siinä on yhteistoiminnallista ja mikä kilpailun sävyttämää, ennen tai vähintäänkin samanaikaisesti kuin lähtee viemään periaatteita luokkahuoneeseen

\section{LÄHTEET}

Aikuiskoulutuksen maailma 2/1993. Kansalais- ja työväenopistojen liiton julkaisu.

Anon. 1990. The Kurt Lewin Cenetary Symposium. Helsingin yliopiston sosiaalipsykologian laitoksen tutkimuksia $3 / 1990$.

Anon. 1993. Aikuisen oppimisen uudet muodot. Vapaan sivistystyön 34. vuosikirja. Helsinki: Kirjastopalvelu Oy.

Argyle, M. 1991. Cooperation. The Basis of Sociability. London: Routledge.
Billig, M. \& al. 1988. Ideological Dilemmas. A Social Psychology of Everyday Thinking. London: Sage Publications Itd.

Deutsch, M. 1990. Kurt Lewin: The Touch-Minded and Tender-Hearted Scientist. In the Kurt Lewin Cenetary Symposium. Helsingin yliopiston sosiaalipsykologian laitoksen tutkimuksia 3/1990.

Hämäläinen, K. \& Mikkola, A. (toim.) 1992. Koulun kehittämisen kansainvälisiä virtauksia. Helsinki: Valtion painatuskeskus.

Johnson, D. \& al. 1984. Circles of Learning. Cooperation in the Classroom. The Assosiation for Supervision and Curriculum Development.

Johnson, D. \& Johnson, F. 1987. Joining Together. Group Theory and Group Skills. Third Edition. New Jersey: Prentice-Hall.

Johnson, D. \& Johnson R. 1989. Cooperation and Competition. Theory and Research. Edina: Interaction Book Company.

Johnson, D. \& Johnson, R. 1992. Yhteistoiminnallinen oppiminen ja koulun kehittäminen. Teoksessa Hämäläinen, K. \& Mikkola, A. (toim.) Koulun kehittämisen kansainvälisiä virtauksia. Helsinki: Valtion painatuskeskus.

Kohonen, V. \& Leppilampi, A. 1992. Kohti yhteistoiminnallista koulukulttuuria - koulunjohdollinen koulutus uusien haasteiden edessä. Teoksessa Hämäläinen, K. \& Mikkola, A. (toim.) Koulun kehittämisen kansainvälisiä virtauksia. Helsinki: Valtion painatuskeskus.

Leppilampi, A. \& Ståhle, P. Yhteistoiminnallinen oppiminen - askel uuteen koulutuskulttuuriin. Opettaja 10/1993.

Sahlberg, P. \& Leppilampi, A. 1993. Yhteistoiminnallisen oppimisen periaatteita. Koulun toiminnan ja oppimisen laadun kehittäminen. Opetusmoniste - Kotola-projekti 1992-94.

Sarala, U. 1993. Työyhteisössä oppiminen - laatupiirit. Teoksessa Aikuisten oppimisen uudet muodot. Vapaan sivistystyön 34. vuosikirja. Helsinki. Kirjastopalvelu Oy.

Schellenberg, J.A. 1988. Sosiaalipsykologian klassikoita. Helsinki: Gaudeamus.

Slavin, R. \& al. (eds.) 1985. Learning to Cooperate, Cooperate to Learn. New York: Plenum Press. 